\title{
Predictors of Employees' Preference for Working from Home Post-Pandemic
}

\author{
Paula M. Caligiuri (Corresponding author) \\ D’Amore-McKim School of Business, Northeastern University \\ 312C Hayden Hall, 360 Huntington Avenue, Boston, MA 02124, USA \\ E-mail: p.caligiuri@northeastern.edu
}

Helen De Cieri

Monash Business School, Monash University

900 Dandenong Road, Caulfield East, Victoria 3145, Australia

E-mail: helen.decieri@monash.edu

\begin{abstract}
Received: February 5, 2021 Accepted: March 12, 2021 Published: March 15, 2021
doi:10.5296/ber.v11i2.18411ＵRL: https://doi.org/10.5296/ber.v11i2.18411
\end{abstract}

\begin{abstract}
The global pandemic of 2020-21 has enabled an examination of the conditions under which working from home is preferred. We examine whether work-life conflict (both work interfering with family and family interfering with work) and need fulfillment (autonomy, relatedness, competence) can be used to predict employees' preference for working from home in the future, post-pandemic. With a sample of 944 employees working from home for the first time, this study found that work-life conflict was negatively related and need fulfillment was positively related to employees' preference for working from home post-pandemic. The experience of having children at home or a partner who was also working from home did not affect employees' long-term preference for working from home; however, being female did. Women were less likely to want to work from home post-pandemic. The implications for ways to maximize the experience of working from home in the future are discussed.
\end{abstract}

Keywords: Work-life balance, Remote work, Flexible work arrangements

\section{Introduction}

In December 2019, a cluster of pneumonia cases was reported by health authorities in Wuhan, 
the capital city of Hubei province in China. The cause was later identified as a novel coronavirus and the resulting illness was named "Coronavirus disease 2019" (COVID-19; World Health Organization (WHO), 2020a). In January 2020, the government of China imposed lockdowns. As the COVID-19 crisis spread across the world, WHO (2020b) declared COVID-19 a pandemic on March 11, 2020. Worldwide, governments imposed travel restrictions, lockdowns or stay-at-home orders, workplace and school closures, banning of mass gatherings, and physical distancing (Cohen \& Kupferschmidt, 2020).

During the first week of April 2020, MIT researchers conducted a survey of 25000 Americans and found that $34.1 \%$ who just four weeks earlier were commuting to work were now working from home (WFH; Brynjolfsson et al., 2020) and these stay-at-home orders are pervasive in almost every country in the world (Cohen \& Kupferschmidt, 2020). A survey conducted with 800 global human resources executives in March 2020 found that $88 \%$ of organizations had either encouraged or required employees to work from home during the COVID-19 crisis (Gartner, 2020). In India, 96\% of organizations surveyed in the last week of March 2020 reported having implemented policies for at least some employees to work from home (CIO, 2020). In the United Kingdom, $60 \%$ of employees are estimated to be WFH during the pandemic (Lilly, 2020).

At the time of writing (February 2021), stay-at-home restrictions are still in place in most countries worldwide; while some restrictions are being lifted, in most countries there is no date set for the easing of restrictions that would allow employees to shift back to their regular workplaces. While the date is unknown, there will be some point in the future when those employees who are currently WFH will have the opportunity or be required to commute to work again. After spending weeks (maybe months) WFH, would employees prefer to continue WFH? Or, if it is required post-pandemic, will commuting to work be more desirable after having the "taste" of WFH? This study attempts to answer these questions by understanding the extent to which employees' current experience of WFH during the COVID-19 pandemic is affecting their preference for WFH post-pandemic. We focus this paper on two broad categories of predictors: (1) the tangible work-life conflict that employees are feeling while WFH and (2) the extent to which their needs are being fulfilled while WFH.

The COVID-19 pandemic is a stark example of disruptive change that has required employers and employees to make rapid adjustments within a short time frame, including a large-scale shift to employees WFH (Einhorn, 2020; Wei \& Wong, 2020). The pandemic of 2020 has enabled an examination of employees' preferences for WFH among individuals who were formerly commuting to work daily (Guyot \& Sawhill, 2020). In normal pre-pandemic employment settings, the opportunity to work from home for all or part of the workweek would be considered part of a flexible work arrangement (FWA) offered through one's employer. There are many different types of FWA, which might include options relating to where to work (flexplace), when to work (flextime), and/or how to work (Chen \& Fulmer, 2018; Hill et al., 2008). WFH, which is one type of FWA that also encompasses telecommuting, remote work, and telework, is not a new phenomenon (Nilles, 1998). WFH or home-based work refers to paid work that is carried out from home, often supported by an array of information, communication, and collaborative technologies (Felstead \& Henseke, 


\section{Macrothink \\ Business and Economic Research \\ ISSN 2162-4860 \\ 2021, Vol. 11, No. 2}

2017; Wilks \& Billsberry, 2007).

The percentage of Americans WFH has not changed for some years. In $200319.6 \%$ of workers were doing some or all of their work from home; this increased to $24 \%$ in 2009, with little change during the decade to 2018 (Bureau of Labor Statistics, 2019). In European Union countries, the percentage of people WFH pre-pandemic ranged from below $10 \%$ in Italy to $37 \%$ in Denmark (Eurofound \& International Labour Office [ILO], 2017). Whatever the level of WFH pre-pandemic, it is likely that the number will increase post-pandemic either because some employees may request a continuance of this arrangement or because some employers may view WFH as a viable option to reduce costs associated with physical space.

Prior to the pandemic, FWAs were found to have positive benefits for employees' health and well-being (Anderson et al., 2015; Boswell et al., 2014) and associated with positive outcomes for employees, such as higher job satisfaction, lower levels of work-life conflict, and lower turnover intention (e.g., Hammer et al., 2005; Masuda et al., 2012). However, WFH has also been criticized due to concerns about surveillance by the employer and loss of privacy (Fairweather, 1999), work intensification, and loss of autonomy for employees (e.g., Felstead \& Henseke, 2017; Kelliher \& Anderson, 2010; Mirchandani, 2000). The pandemic may have worsened these concerns because the WFH was involuntary and ongoing, both conditions that can cause greater work-life conflict (Kaduk et al., 2019; Spieler et al., 2017) by leading to an increase in employees' work hours and a reduction in their capacity to address their personal and family needs (Richman et al., 2008). Table 1 summarizes the difference between the pre-pandemic voluntary or volitional WFH experience and the during-pandemic involuntary WFH experience. 
Table 1. WFH: Comparing Volitional and Involuntary Situations

\begin{tabular}{|l|l|}
\hline Pre-pandemic WFH: Voluntary and volitional & During-pandemic WFH: Involuntary and ongoing \\
\hline $\begin{array}{l}\text { Initiated by the employee or entered into willingly as } \\
\text { part of a desired FWA. }\end{array}$ & $\begin{array}{l}\text { Employer and employee have no choice: the WFH } \\
\text { policy was imposed by government decisions for } \\
\text { workplace closures and stay-at-home rules. }\end{array}$ \\
\hline $\begin{array}{l}\text { Likely to have been planned and negotiated and to have } \\
\text { clearly defined contractual arrangements, resources, and } \\
\text { an end date. }\end{array}$ & $\begin{array}{l}\text { Imposed with short notice and little planning, no } \\
\text { clear end date, and resources that may be limited } \\
\text { (perhaps due to cost constraints under current crisis } \\
\text { conditions). }\end{array}$ \\
\hline $\begin{array}{l}\text { Might have been "home alone" or perhaps with } \\
\text { pre-school children. Time was available to make } \\
\text { alternate arrangements for children who would be at } \\
\text { home while parent was WFH. }\end{array}$ & $\begin{array}{l}\text { May have a full house such that the whole household } \\
\text { is there all the time. No childcare is available. }\end{array}$ \\
\hline $\begin{array}{l}\text { School-age children were usually at school during the } \\
\text { school year. }\end{array}$ & $\begin{array}{l}\text { Due to school closures, school-age children are } \\
\text { learning at home; there is no clear date for schools to } \\
\text { resume. }\end{array}$ \\
\hline $\begin{array}{l}\text { Information and communication technologies (ICTs) } \\
\text { were available and there may have been support and } \\
\text { resources in place to allow time for individuals to } \\
\text { become familiar with them. }\end{array}$ & $\begin{array}{l}\text { The short time frame requires rapid adoption of } \\
\text { ICTs. Some employees do not have home offices or } \\
\text { space to allocate for work. }\end{array}$ \\
\hline $\begin{array}{l}\text { No daily commute required. } \\
\text { The context was a healthy social environment. }\end{array}$ & $\begin{array}{l}\text { No daily commute permitted and there are } \\
\text { restrictions on movement outside the home. }\end{array}$ \\
\hline $\begin{array}{l}\text { The context is a global pandemic. } \\
\text { work, possibly in combination with work performed at } \\
\text { the regular workplace. }\end{array}$ & $\begin{array}{l}\text { There is no socializing outside of work. } \\
\text { to be performed at home. }\end{array}$ \\
\hline
\end{tabular}

The current pandemic situation enables us to explore whether employees would welcome (or reject) the idea of WFH in the post-pandemic future. Even though WFH now is not by choice, some employees may find that it has been a positive experience, possibly better than expected. On the contrary, others might discover that they would prefer a physical separation between their work and home lives and prefer to be back in their workplace as soon as possible. To better understand who has a higher preference for WFH after the pandemic, we examine both the work-life conflict and the extent to which individuals' needs are being fulfilled while WFH.

\subsection{WFH and Work-Life Conflict}

FWAs, in general, and WFH, specifically, have been welcomed as an opportunity to reduce work-family conflict (e.g., Fletcher \& Bailyn, 1996) as they provide scheduling flexibility (e.g., allowing work to be adjusted around childcare), save time usually spent on the daily commute, and improve work-family integration by offering more opportunities for family communication (Mirchandani, 2000). However, not all the effects of FWAs are positive; “... while remote working is associated with higher organisational commitment, job satisfaction and job-related well-being, these benefits come at the cost of work intensification and a greater inability to switch off' (Felstead \& Henseke, 2017, p. 195). The boundaries between work and personal/family life affect the way that employees experience FWAs such as WFH (Cañibano, 2019; Kelliher \& Anderson, 2010). Involuntary WFH during the pandemic has 
dissolved almost everyone's ability to concentrate only on work when at work and only on home life when at home. The boundary concerns have likely been amplified for those WFH for the first time.

\subsubsection{Work Interfering with Personal/Family Life}

Having strong boundaries at home, where work does not interfere with one's personal life, is a condition under which FWAs, such as flextime and flexplace, positively affect employees' well-being (Spieler et al., 2017), psychophysiological arousal (e.g., epinephrine levels; Lundberg \& Lindfors, 2002), self-reported stress and strain, and physical health (Butler et al., 2009). The more WFH causes employees to associate their homes with work, the more work will interfere with family/personal time (Eddleston \& Mulki, 2017) and the more they will feel bound to doing more work "off-hours" to demonstrate their organizational commitment (Gajendran et al., 2015). FWAs, under normal situations, do prompt work to negatively interfere with family more than family interferes with work, especially for those employees with greater family responsibilities (Shockley \& Allen, 2007).

With involuntary WFH, where employees are required to make the shift to home at short notice, perhaps without planning and setting up a workspace at home, work will likely interfere with family life (Tietze \& Musson, 2005). For those employees, the difficulties associated with work interfering with family life might deter them from wishing to continue the WFH arrangement, even after stay-at-home restrictions are lifted. However, employees who have been able to shift their work into their home without interfering with or imposing on family/personal life may find it relatively easy to adapt to this way of working and be positively disposed toward it. We hypothesize:

H1a. Employees who have experienced less work interference with family/personal life while WFH involuntarily during the COVID-19 pandemic will have a higher preference for WFH after the pandemic.

\subsubsection{Personal/Family Life Interfering with Work}

With children home who likely need caregiving, homeschooling, or supervision by the parent or caregiver who is WFH, there is a greater possibility of one's personal life interfering with work (Byron, 2005; Weber, 2020). Similarly, if multiple, co-located adult family members are WFH and are engaged in work-related activities, then their ability to concentrate might be limited unless their residence is large enough to accommodate more than one working adult, also causing work interference. Our definition of family life is inclusive of all family forms and recognizes that, whatever the co-located family unit, additional people will add additional opportunities for interference. We hypothesize:

H1b. Employees who have experienced less family/personal life interference with work while WFH involuntarily during the COVID-19 pandemic will have a higher preference for WFH after the pandemic.

\subsection{Need Fulfillment and Preference for WFH}

We posit that the nature of employees' current experience when WFH will predict their future 
motivation for or interest in continuing to work from home. From a theoretical perspective, human motivation for continuing an activity can be understood based on whether needs are fulfilled during an activity. According to self-determination theory, human behavior is motivated, universally, to fulfill three basic psychological needs: autonomy, competence, and relatedness (Deci et al., 2017; Deci \& Ryan, 2000, 2002; Ryan \& Deci, 2000). The need for autonomy reflects our innate desire to ensure concordance between our values and our behaviors. With greater autonomy, one has more freedom and control to ensure concordance. The need for relatedness represents how humans are social animals who seek opportunities to connect in meaningful ways with others. The need for competence reflects one's desire to meet the challenges present in the environment without having too much stress or too little challenge in one's life. According to self-determination theory, what is important is not the strength of the needs felt by an individual but the extent to which that individual is able to satisfy their needs within a given social context (Deci et al., 2017).

When self-determination theory is applied to employment settings, employees who have their basic psychological needs met have more positive work outcomes, such as a higher level of job satisfaction (Graves \& Luciano, 2013), greater organizational commitment (Rasskazova et al., 2016), better psychological well-being in the workplace (Gomez-Baya \& LuciaCasademunt, 2018; Ilardi et al., 1993), and higher job performance (Baard et al., 2004). Self-determination theory suggests that when an individual's way of working is volitionally enacted, self-endorsed, and personally meaningful, their quality of experiences and their motivation to engage in work will be enhanced (Deci \& Ryan, 2000; Deci et al., 2017; Van den Broeck et al., 2016). Thus, when WFH enables their needs to be met, people should function effectively in both work and family/personal roles and be willing to continue their current arrangements.

While WFH during the COVID-19 pandemic, individuals should experience need fulfillment for them to desire a future opportunity to work from home. Each of the primary needs in self-determination theory (autonomy, relatedness, and competence) has the potential to be influenced when employees are WFH. By examining the unique setting of involuntary WFH during a crisis, our research responds to calls such as that by Wayne et al. (2019) for studies to examine situational factors that fulfill individual needs such as the need for autonomy. The specific relationships between WFH and the fulfillment of each psychological need are described in greater detail in the following subsections.

\subsubsection{Need for Autonomy}

The outcomes of FWAs are better when employees have full autonomy to control when and how they work without overly restrictive external controls (Gerdenitsch et al., 2015). The notion of autonomy is central to self-determination theory (Gagné \& Deci, 2005) and studies have shown that where employees feel that they have autonomy and this is supported within their work context, this leads to an increase in intrinsic motivation (Gagné et al., 1997). As the period of WFH continues, and employees have a heightened sense of autonomy, they might prefer to continue WFH longer term. We hypothesize:

H2a. Employees who have experienced fulfillment in their need for autonomy while 
WFH involuntarily during the COVID-19 pandemic will have a higher preference for WFH after the pandemic.

\subsubsection{Need for Relatedness}

Gajendran and Harrison (2007) conducted a meta-analysis about the consequences of WFH and found that relationships with colleagues were harmed when they worked three or more days each week from home. It appears that some touch point is needed for employees to feel a sense of connectedness with their co-workers. Since WFH during this pandemic leaves no opportunity for in-person interactions, the social support and collaboration would need to be fulfilled through phone calls, conference calls, and other communication technologies. For some, the experience of using these technologies to stay connected with co-workers could be positive as they are "all in the same boat," so to speak. For others, the absence of in-person interactions with colleagues may be demotivating (Deci et al., 2017). The level of fulfillment in an employee's need for relatedness would have an implication for whether they would want to continue WFH post-pandemic. We hypothesize:

H2b. Employees who have experienced fulfillment in their need for relatedness while WFH involuntarily during the COVID-19 pandemic will have a higher preference for WFH after the pandemic.

\subsubsection{Need for Competence}

Whether in sports, academics, or work-related tasks, research has found that felt competence influences subsequent motivation, especially among those with a higher need for achievement (Schüler et al., 2010). How one experiences felt competence while WFH might depend on the nature of the task. For example, employees working in more complex jobs that did not require collaboration had better performance when WFH than when working at an organization (Golden \& Gajendran, 2018). Consistent with Schüler et al.'s (2010) findings, employees' felt competence should affect their subsequent desire to continue WFH. We hypothesize:

H2c. Employees who have experienced fulfillment in their need for competence while involuntarily WFH during the pandemic will have a higher preference for WFH after the COVID-19 pandemic.

\section{Methods}

\subsection{Sample}

On April 21, 2020, an MTurk study was conducted with the intention of gathering 1000 usable responses from those who were WFH for the first time. Initially, 1385 participants began the survey but 441 were disqualified because they were not new to WFH or not currently WFH. The resulting sample size was $n=944$. Among this group of participants, $69 \%$ were male ( $31 \%$ were female and less than $1 \%$ non-binary), $75 \%$ were American (13\% Indian, $4 \%$ Brazilian, 2\% Canadian, 1\% Italian, and 1\% each for 10 other countries). The participants were $85.5 \%$ full-time employees working an average of 32.2 hours per week from home $(\mathrm{SD}=13.3$ hours). Most of the sample was married or living with a partner (78\%) and had 
children with them at home during the pandemic (59\%). The average age of the sample was 34.2 years $(\mathrm{SD}=9.9$ years $)$.

\subsection{Measures}

\subsubsection{Control Variables}

The study controlled for the demographic variables that would make WFH more difficult. The survey included questions on whether there was at least one child living at home (1=Yes; $0=\mathrm{No})$, whether a spouse or partner was also WFH $(1=$ Yes; $0=\mathrm{No})$, whether the participant was female $(1=$ Yes; $0=$ No) and the number of hours working each week. We also controlled for participant age (if younger, more tech savvy, would prefer WFH) and whether the participant was American (known for being more individualistic).

\subsubsection{Work-Life Conflict}

The 10-item scale developed by Netemeyer et al. (1996) was used to measure the extent to which there was incompatibility between employees' work and family domains. There were two sub-dimensions of this scale: Work Interfering with Family (5 items) and Family Interfering with Work (5 items). The items were assessed on 6-point Likert scales (1=Strongly disagree to $6=$ Strongly agree). The alpha coefficient of the Work Interfering with Family scale was $\alpha=91$. Sample items include "The amount of time my job takes up makes it difficult to fulfill family responsibilities" and "My job produces strain that makes it difficult to fulfill family duties." A high score equals a high level of the work domain interfering with the family domain. The alpha coefficient of the Family Interfering with Work scale was $\alpha=93$. Sample items include "Things I want to do at work don't get done because of the demands of my family or spouse/partner" and "Family-related strain interferes with my ability to perform job-related duties." A high score equals a high level of the family domain interfering with the work domain.

\subsubsection{Need Fulfillment}

The 12-item Basic Psychological Needs at Work scale (Brien et al., 2012) was adapted for this study. This study assessed whether employees' Need for Autonomy (4 items), Need for Relatedness (4 items), and Need for Competence (4 items) were being met while WFH. The items were assessed on 6 -point Likert scales ( $1=$ Strongly disagree to $6=$ Strongly agree). The alpha coefficient of the Need for Autonomy scale was $\alpha=71$. A sample item is "While working from home, I feel free to execute my tasks in my own way." A high score equals a high fulfillment of the participant's need for autonomy. The alpha coefficient of the Need for Relatedness scale was $\alpha=82$. A sample item is "When interacting virtually with work colleagues, I feel heard." A high score equals a high fulfillment of the participant's need for relatedness. The alpha coefficient of the Need for Competence scale was $\alpha=74$. A sample item is "I succeed in my work while working from home." A high score equals a high fulfillment of the participant's need for competence.

\subsubsection{Preference for WFH}

A 7-item scale was developed for this study to measure the extent to which an employee 


\section{Macrothink}

Business and Economic Research

ISSN 2162-4860

2021, Vol. 11, No. 2

would like to continue WFH post-pandemic. The items were assessed on 6-point Likert scales ( $1=$ Strongly disagree to $6=$ Strongly agree). The alpha coefficient of this scale was $\alpha=87$. A sample item is "If I can work from home in the future, I would like to do so." A high score equals a strong preference to work from home.

\section{Results}

Table 2 presents the bivariate correlations of all control, independent, and dependent variables included in these analyses. To test hypotheses $1 \mathrm{a}$ and $1 \mathrm{~b}$, preference for WFH was regressed on the two work-life interference dimensions after controlling for demographics (see Table 3). Work interfering with personal/family life was a significant predictor of employees' preference to continue WFH after the pandemic. Personal/family life interfering with work life was not significant. Hypothesis 1a was supported but hypothesis $1 \mathrm{~b}$ was not supported. Given the high correlation between the "Family interfering with work" and "Work interfering with family" variables, we combined those to a single work-life conflict variable. The alpha coefficient for the combined scale was $\alpha=95$. In this post hoc regression result, the combined work-life conflict variable was a significant predictor of preference for WFH. The regression model is presented in Table 3.

To test hypotheses $2 \mathrm{a}, 2 \mathrm{~b}$, and $2 \mathrm{c}$, preference for WFH was regressed on the three needs after controlling for demographics and entering the two work-life interference dimensions. In this model, the fulfillment of one's need for competence was significant in the predicted direction. Hypothesis $2 \mathrm{c}$ was supported but hypotheses $2 \mathrm{a}$ and $2 \mathrm{~b}$ were not supported. Given the high correlation among the "Need for autonomy," "Need for relatedness," and "Need for competence" variables, we combined those to a single need fulfillment variable. The alpha coefficient for the combined scale was $\alpha=.88$. In this post hoc regression result, the combined need fulfillment variable was a significant predictor of preference for WFH. The regression model is presented in Table 3. 
Table 2. Descriptive Statistics and Correlations

\begin{tabular}{|c|c|c|c|c|c|c|c|c|c|c|c|c|c|c|}
\hline & $\begin{array}{l}\text { Mea } \\
n\end{array}$ & SD & Child & $\begin{array}{l}\text { Spou } \\
\text { s }\end{array}$ & Fem & Age & $\begin{array}{l}\text { Amer } \\
\text { i }\end{array}$ & $\begin{array}{l}\text { Hour } \\
\mathrm{s}\end{array}$ & WIF & FIW & $\begin{array}{l}\text { Auto } \\
\mathrm{n}\end{array}$ & Relat & $\begin{array}{l}\text { Com } \\
p\end{array}$ & $\begin{array}{l}\text { Prefe } \\
\mathrm{r}\end{array}$ \\
\hline $\begin{array}{l}\text { Child at } \\
\text { home }\end{array}$ & .54 & .50 & - & & & & & & & & & & & \\
\hline $\begin{array}{l}\text { Spouse at } \\
\text { home }\end{array}$ & .34 & .47 & $.27^{* *}$ & - & & & & & & & & & & \\
\hline Female & .31 & .46 & $.16^{* * *}$ & $.21 * *$ & - & & & & & & & & & \\
\hline Age & 34.2 & 9.9 & -.01 & .05 & $.10 *$ & - & & & & & & & & \\
\hline American & .75 & .43 & $.21 * *$ & $.21 * *$ & $.22 * *$ & $.27 * *$ & - & & & & & & & \\
\hline $\begin{array}{l}\text { Hours } \\
\text { working } \\
\text { per week }\end{array}$ & 32.3 & $\begin{array}{l}13 . \\
3\end{array}$ & .03 & .03 & .03 & $.14 * *$ & .05 & - & & & & & & \\
\hline $\begin{array}{l}\text { Work } \\
\text { interfering } \\
\text { w/ family }\end{array}$ & 3.62 & $\begin{array}{l}1.3 \\
0\end{array}$ & $.30^{* * *}$ & .01 & $\begin{array}{l}-.11 * \\
*\end{array}$ & $\begin{array}{l}-.19 * \\
*\end{array}$ & -.16 & .01 & $(.91)$ & & & & & \\
\hline $\begin{array}{l}\text { Family } \\
\text { interfering } \\
\text { w/ work }\end{array}$ & 3.50 & $\begin{array}{l}1.3 \\
8\end{array}$ & $.33 * *$ & .01 & $\begin{array}{l}-.15^{*} \\
*\end{array}$ & $\begin{array}{l}-.22 * \\
*\end{array}$ & -.17 & -.06 & $.86^{* * *}$ & $(.93)$ & & & & \\
\hline $\begin{array}{l}\text { Need for } \\
\text { autonomy }\end{array}$ & 4.89 & .73 & $\begin{array}{l}-.09^{*} \\
* \\
\end{array}$ & .03 & .03 & $.10^{* * *}$ & .08 & .06 & $\begin{array}{l}-.23^{*} \\
* \\
\end{array}$ & $\begin{array}{l}-.21 * \\
* \\
\end{array}$ & (.71) & & & \\
\hline $\begin{array}{l}\text { Need for } \\
\text { relatedness }\end{array}$ & 4.71 & .76 & -.02 & $.11 *$ & -.01 & $.08 *$ & .02 & $.09^{*}$ & $\begin{array}{l}-.11^{*} \\
* \\
\end{array}$ & $\begin{array}{l}-.13^{*} \\
*\end{array}$ & $.59 * *$ & $(.74)$ & & \\
\hline $\begin{array}{l}\text { Need for } \\
\text { competenc } \\
\text { e }\end{array}$ & 4.80 & .84 & $\begin{array}{l}-.10^{*} \\
*\end{array}$ & .04 & .02 & .03 & .03 & .03 & $\begin{array}{l}-.28^{*} \\
*\end{array}$ & $\begin{array}{l}-.27 * \\
*\end{array}$ & $.70 * *$ & $\begin{array}{l}.55^{*} \\
*\end{array}$ & $(.82)$ & \\
\hline $\begin{array}{l}\text { Preference } \\
\text { for WFH }\end{array}$ & 3.57 & $\begin{array}{l}1.0 \\
5\end{array}$ & $-.08^{*}$ & -.05 & $-.06^{*}$ & -.03 & -.01 & -.02 & $\begin{array}{l}-.21 * \\
*\end{array}$ & $\begin{array}{l}-.17 * \\
*\end{array}$ & $.24 * *$ & .05 & $.40 * *$ & (.87) \\
\hline
\end{tabular}

Notes: $* \underline{p}<.05 ; * * \underline{*}<.01$; coefficient $\alpha$ for each multi-item variable is in the diagonal.

Table 3. Regression Analyses Predicting Preference for WFH

\begin{tabular}{|l|l|l|l|l|}
\hline & Model 1 & Model 2 & Model 1 (comb.) & Model 2 (comb.) \\
\hline Child at home during pandemic & -.01 & -.01 & -.01 & -.01 \\
\hline Spouse/partner WFH & -.04 & -.03 & -.04 & -.06 \\
\hline Female & $-.08^{*}$ & $-.08^{*}$ & $-.08^{*}$ & $-.08^{*}$ \\
\hline Age & -.06 & -.04 & -.06 & $-.07 *$ \\
\hline American & -.04 & -.02 & -.04 & -.03 \\
\hline Hours working per week & .04 & .03 & .03 & .01 \\
\hline Work interfering with family & $-.24 * * *$ & $-.14 *$ & & \\
\hline Family interfering with work & -.01 & .04 & & \\
\hline Need fulfillment - autonomy & & .03 & & \\
\hline Need fulfillment - relatedness & & $-.25^{* * *}$ & & \\
\hline Need fulfillment - competence & & $.49 * * *$ & & $-.17 * * *$ \\
\hline Work-life conflict (combined) & & & $-.23 * * *$ & $.24 * * *$ \\
\hline Need fulfillment (combined) & & & & .05 \\
\hline$\Delta$ R2 & & .17 & & .11 \\
\hline R2 & .06 & .23 & .06 & .10 \\
\hline AdjustedR2 & .05 & .22 & .05 & $14.23 * * *$ \\
\hline F & $7.52 * * *$ & $24.19 * * *$ & $7.96 * * *$ & \\
\hline
\end{tabular}

Notes: Standardized betas presented in the table: ${ }^{*} \underline{p}<.05 ; * * \underline{p}<.01 ; * * * p<.001$.

\section{Discussion}

This study contributes to the literature by investigating whether (and under what 
circumstances) employees' experience of involuntarily WFH during the COVID-19 pandemic affects their interest in WFH voluntarily in the future. We found that work-life conflict was a predictor of whether employees would prefer to work from home in the post-pandemic future. While facilitating or impeding work-life conflict has long been identified as an outcome of FWAs (e.g., Boswell et al., 2014; Felstead \& Henseke, 2017), future studies should consider work-life conflict as a predictor, as in this study, to determine whether the removal of conditions causing work-life conflict causes a greater use of WFH options.

In this study, all employees were WFH involuntarily, holding the voluntary nature of WFH constant. Kaduk et al. (2019) found that employees who were engaged in remote work that was against their wishes reported higher levels of work-family conflict. Even though it was imposed, we still found variance in the experience such that some wanted the WFH policy to continue, after the pandemic. More research is needed to better understand how companies implementing WFH policies in the future can optimize the experience for employees.

Applying self-determination theory, need fulfillment was also important for predicting whether employees will want to continue WFH. Having one's competence needs fulfilled was related to a higher preference for WFH in the future. An explanation for this finding might be that, with widespread use of communication technology, employees are likely to be in regular contact with their supervisor and receiving feedback. According to self-determination theory, feedback is an important factor for an individual's need for competence to be satisfied (Deci et al., 2017; Van den Broeck et al., 2016). Future studies should examine this further to determine whether structural changes could be made to how work is accomplished to enable employees to receive the necessary reward and recognition while WFH.

Examining the bivariate correlations, whether one's need for autonomy was fulfilled was correlated to employees' future desire to work from home; however, the high correlation with need for competence resulted in no additional variance predicted. Behaviors that are externally regulated or "initiated and maintained by contingencies external to the person" (Gagné \& Deci, 2005, p. 334) foster desirable organizational outcomes but only to avoid undesirable outcomes. In the case of involuntary WFH, employees might have had little autonomy in the initial decision to shift their work to home and likely did not have a choice in the collaborative technologies the companies employed. At the same time, they are now working without any in-person supervision. Future research should examine whether employees' ability to control when and how they work from home would affect whether they desire to continue WFH.

Examining the bivariate correlations, whether one's need for relatedness was fulfilled was not correlated to employees' future desire for WFH. When "Need for relatedness" was entered as an independent variable, the results were opposite from what was hypothesized, such that the more individuals' need for relatedness is being met while WFH, the less likely it is that they will want to continue. This finding was counterintuitive from a need fulfillment perspective, but it is consistent with the concept of belonging, which is related to how meaningful life is perceived to be (Lambert et al., 2013). It might be the case that when employees felt that their need for friendship and trust with their co-workers was being satisfied WFH, they were 
reminded of the sense of belonging they once experienced when co-located and genuinely missed seeing their co-workers, in person, on a regular basis. Future studies should explore the role of employees' need for relatedness in relationships between the social influence of the workplace and employees' interest in WFH in the future.

We controlled for the variables that were likely to have an influence on the type of experience employees were having during involuntary WFH. Of the variables tested, being female was a significant predictor in all the regression models. Women were less likely to want to work from home in the future. Our findings are consistent with the body of literature that shows that FWAs, such as WFH, are experienced differently between men and women. Previous studies have shown that there are career penalties for women using FWAs which are not present for men (Chung \& Van der Horst, 2018). Research suggests that women who work from home tend to fulfill normative gender roles such that they tend to (or are expected to) increase their family responsibilities, while men WFH tend to (or are expected to) prioritize their work (Hilbrecht et al., 2013). Irrespective of the actual priorities, women are more likely to face negative career outcomes due to WFH, compared to their male counterparts (Chung, 2018). This could explain their reluctance to continue WFH post-pandemic. Future research might explore the implications of the widespread, first-time experience of enforced WFH for either reduction or reinforcement of entrenched gender roles and societal expectations in the long term.

Our sample was $75 \%$ American. As this pandemic affected employees WFH almost everywhere in the world, future studies should apply self-determination theory to examine work-life conflict and WFH preferences across countries. This would be particularly important given that FWAs are adopted differentially across countries based on labor laws and cultural differences (e.g., Ollier-Malaterre et al., 2013; Powell et al., 2009). Previous research has found that national cultural values were related to the outcomes of FWAs, suggesting that use of FWAs reduces absenteeism and turnover more when such use is consistent with national cultural values (Peretz et al., 2018).

\subsection{Limitations}

Having everyone WFH at the same time provided a way to determine employees' preferences for the experience of WFH. However, this "taste" of WFH is under difficult circumstances (e.g., health-related concerns and caring for family members) and the true number of people who would like WFH might be higher in a less stressful context. While we believe that the patterns of findings have important implications for the future of WFH policies, we need future research to examine these findings in a post-pandemic climate. Further, considering this in combination with the autonomy and relatedness results, future research might explore whether WFH is better suited to some populations (i.e., those who appreciate autonomy and perhaps are less concerned about relatedness).

This study was cross-sectional, designed to capture the sentiments of workers who started WFH for the first time during the COVID-19 pandemic. While Ko and Kim (2018) suggest that the intention to use FWAs affects their actual use, future studies should examine actual behavior. For example, future studies could track which companies offer WFH as an option 
and the extent to which employees' experience during the pandemic affects whether they opt to work from home in the future.

\subsection{Practical Implications}

Industry surveys suggest that WFH in the post-pandemic world will be more widespread (GlobalWorkplaceAnalytics.com, 2020). As this is likely the case, our study adds context for employers to better understand the conditions under which employees may welcome this opportunity. Our study could help inform companies seeking to either maintain or introduce WFH. To reduce work-life conflict for employees WFH, managers could encourage "hard stops" and clear break times so that employees can switch off from work (Chen \& Fulmer, 2018). There could be a more open dialogue about caregiving responsibilities and whether flextime while WFH would be possible to meet those demands.

Prior to the pandemic, managerial backlash based on a general lack of trust of employees produced employees' fear of negative career consequences and a reluctance to work from home (Leslie et al., 2012). Now that managers have had the experience of WFH themselves, backlash against employees who work from home might be reduced. However, since our study suggests that the experience of WFH varied, if companies do implement widespread WFH policies, they should be cognizant of whether backlash remains among some managers (perhaps those who had a negative experience with WFH during the pandemic). It is also important to recognize that the pandemic-related restrictions have already caused high levels of unemployment in many countries which will likely result in ongoing job insecurity going forward. In this context, employees will be less likely to voice or act on their preference to work from home, due to fears that their managers will view a preference for WFH as a lack of work commitment (Boswell et al., 2014).

During the COVID-19 pandemic, the shift to WFH happened with little warning and for many who were new to WFH there was no time for preparation or training. To prepare managers for the future world of work, in which more people will likely be WFH, training and additional resources should be provided to support collaboration, use of technology, workflow, remote leadership, and the like. We believe that companies who have the best ability to motivate, engage, and mobilize their workforce remotely will be most able to harness their collective talent to realize desired outcomes for individuals, such as greater employee well-being and performance, and to gain competitive advantage.

\section{References}

Anderson, A. J., Kaplan, S. A., \& Vega, R. P. (2015). The impact of telework on emotional experience: When, and for whom, does telework improve daily affective well-being? European Journal of Work and Organizational Psychology, 24, 882-897. https://doi.org/10.1080/1359432X.2014.966086

Baard, P., Deci, E., \& Ryan, R. (2004). Intrinsic need satisfaction: A motivational basis of performance and well-being in two work settings. Journal of Applied Social Psychology, 34, 2045-2068. https://doi.org/10.1111/j.1559-1816.2004.tb02690.x 
Boswell, W. R., Olson-Buchanan, J. B., \& Harris, T. B. (2014). I cannot afford to have a life: Employee adaptation to feelings of job insecurity. Personnel Psychology, 67, 887-915. https://doi.org/10.1111/peps.12061

Brien, M., Forest, J., Mageau, G., Boudrias, J., Desrumaux, P., Brunet, L., \& Morin, E. (2012). The Basic Psychological Needs at Work scale: Measurement invariance between Canada and France. Applied Psychology: Health and Well-Being, 4, 167-187.

https://doi.org/10.1111/j.1758-0854.2012.01067.x.

Brynjolfsson, E., Horton, J., Ozimek, A., Rock, D., Sharma, G., \& Ye, H. Y. T. (2020). COVID-19 and remote work: An early look at US data. Unpublished manuscript. https://doi.org/10.3386/w27344

Bureau of Labor Statistics. (2019). American Time Use Survey - 2018 Results, News Release. [Online] Available: https://www.bls.gov/news.release/pdf/atus.pdf

Butler, A., Grzywacz, J., Ettner, S., \& Liu, B. (2009). Workplace flexibility, self-reported health, and health care utilization. Work and Stress, 23, 45-59.

https://doi.org/10.1080/02678370902833932

Byron, K. (2005). A meta-analytic review of work-family conflict and its antecedents. Journal of Vocational Behavior, 67, 169-198. https://doi.org/10.1016/j.jvb.2004.08.009

Cañibano, A. (2019). Workplace flexibility as a paradoxical phenomenon: Exploring employee experiences. Human Relations, 72, 444-470.

https://doi.org/10.1177/0018726718769716

Chen, Y., \& Fulmer, I. S. (2018). Fine-tuning what we know about employees' experience with flexible work arrangements and their job attitudes. Human Resource Management, 57, 381-395. https://doi.org/10.1002/hrm.21849

Chung, H. (2018). Women's work penalty in the access to flexible working arrangements across Europe. European Journal of Industrial Relations, 25, 23-40.

https://doi.org/10.1177/0959680117752829

Chung, H., \& Van der Horst, M. (2018). Women's employment patterns after childbirth and the perceived access to and use of flexitime and teleworking. Human Relations, 71, 47-72. https://doi.org/10.1177/0018726717713828

CIO. (2020). [Online] Available: https://www.cio.com/article/3533248/coronavirus-lockdown -leads-to-an-enterprise-wide-work-from-home-wfh-in-india.html

Cohen, J., \& Kupferschmidt, K. (2020). Mass testing, school closings, lockdowns: Countries pick tactics in 'war' against coronavirus. Science. https://doi.org/10.1126/science.abb7733

Deci, E. L., \& Ryan, R. M. (2000). The "what" and "why" of goal pursuits: Human needs and the self-determination of behavior. Psychological Inquiry, 11, 227-268.

https://doi.org/10.1207/S15327965PLI1104_01

Deci, E. L., \& Ryan, R. M. (2002). Handbook of self-determination research. University of 
Rochester Press.

Deci, E. L., Olafsen, A. H., \& Ryan, R. M. (2017). Self-determination theory in work organizations: The state of a science. Annual Review of Organizational Psychology and Organizational Behavior, 4, 19-43. https://doi.org/10.146/annurev-orgpsych-032516-113108

Eddleston, K. A., \& Mulki, J. (2017). Toward understanding remote workers' management of work-family boundaries: The complexity of workplace embeddedness. Group \& Organization Management, 42, 346-387. https://doi.org/10.1177/1059601115619548

Einhorn, C. S. (2020, April 26). How corporate managers are coping with working from home. Barron's. [Online] Available: https://www.barrons.com/articles/how-corporate-manage rs-are-coping-with-working-from-home-51587907790

Eurofound \& International Labour Office [ILO]. (2017). Working anytime, anywhere: The effects on the world of work. Publications Office of the European Union, Luxembourg, and the International Labour Office.

Fairweather, B. (1999). Surveillance in employment: The case of teleworking. Journal of Business Ethics, 22, 39-49. https://doi.org/10.1023/A:1006104017646

Felstead, A., \& Henseke, G. (2017). Assessing the growth of remote working and its consequences for effort, well-being and work-life balance. New Technology, Work and Employment, 32, 195-212. https://doi.org/10.1111/ntwe.12097

Fletcher, J. K., \& Bailyn, L. (1996). Challenging the last boundary: Reconnecting work and family. In M. Arthur \& D. M. Rousseau (Eds.), The boundaryless career (pp. 256-267). Oxford University Press.

Gagné, M., \& Deci, E. L. (2005). Self-determination theory and work motivation. Journal of Organizational Behavior, 26, 331-362. https://doi.org/10.1002/job.322

Gagné, M., Senecal, C. B., \& Koestner, R. (1997). Proximal job characteristics, feelings of empowerment, and intrinsic motivation: A multidimensional model. Journal of Applied Social Psychology, 27, 1222-1240. https://doi.org/10.1111/j.1559-1816.1997.tb01803.x

Gajendran, R. S., \& Harrison, D. A. (2007). The good, the bad, and the unknown about telecommuting: Meta-analysis of psychological mediators and individual consequences. Journal of Applied Psychology, 92, 1524-1541. https://doi.org/10.1037/0021-9010.92.6.1524

Gajendran, R. S., Harrison, D. A., \& Delaney-Klinger, K. (2015). Are telecommuters remotely good citizens? Unpacking telecommuting's effects on performance via i-deals and job resources. Personnel Psychology, 68, 353-393. https://doi.org/10.1111/peps.12082

Gartner. (2020). Gartner HR survey reveals $88 \%$ of organizations have encouraged or required employees to work from home due to coronavirus. [Online] Available:

https://www.gartner.com/en/newsroom/press-releases/2020-03-19-gartner-hr-survey-reveals-8 8--of-organizations-have-e

Gerdenitsch, C., Kubicek, B., \& Korunka, C. (2015). Control in flexible working 
arrangements. Journal of Personnel Psychology, 14(2), 61-69.

https://doi.org/10.1027/1866-5888/a000121

GlobalWorkplaceAnalytics.com. (2020). Work-at-home after COVID-19-our forecast. [Online] Available: https://globalworkplaceanalytics.com/work-at-home-after-covid-19-our-forecast

Golden, T. D., \& Gajendran, R. (2018). Unpacking the role of a telecommuter's job in their performance: Examining job complexity, problem solving, interdependence, and social support. Journal of Business and Psychology, 34, 55-69.

https://doi.org/10.1007/s10869-018-9530-4

Gomez-Baya, D., \& Lucia-Casademunt, A. (2018). A self-determination theory approach to health and well-being in the workplace: Results from the sixth European working conditions survey in Spain. Journal of Applied Social Psychology, 48, 269-283.

https://doi.org/10.1111/jasp.12511

Graves, L., \& Luciano, M. (2013). Self-determination at work: Understanding the role of leader-member exchange. Motivation and Emotion, 37, 518-536.

https://doi.org/10.1007/s11031-012-9336-z

Guyot, K., \& Sawhill, I. V. (2020). Telecommuting will likely continue long after the pandemic. Brookings Institute. [Online] Available: https://www.brookings.edu/blog/up-front /2020/04/06/telecommuting-will-likely-continue-long-after-the-pandemic/

Hammer, L. B., Neal, M. B., Newsom, J. T., Brockwood, K. J., \& Colton, C. L. (2005). A longitudinal study of the effects of dual-earner couples' utilization of family-friendly workplace supports on work and family outcomes. Journal of Applied Psychology, 90, 799-810. https://doi.org/10.1037/0021-9010.90.4.799

Hilbrecht, M., Shaw, S. M., Johnson, L. C., \& Andrey, J. (2013). Remixing work, family and leisure: Teleworkers' experiences of everyday life. New Technology, Work and Employment, 28, 130-144. https://doi.org/10.1111/ntwe.12010

Hill, E. J., Grzywacz, J. G., Allen, S., Blanchard, V. L., Matz-Costa, C., Shulkin, S., \& Pitt-Catsouphes, M. (2008). Defining and conceptualizing workplace flexibility. Community, Work and Family, 11, 149-163. https://doi.org/10.1080/13668800802024678

Ilardi, B. C., Leone, D., Kasser, T., \& Ryan, R. M. (1993). Employee and supervisor ratings of motivation: Main effects and discrepancies associated with job satisfaction and adjustment in a factory setting. Journal of Applied Social Psychology, 23, 1789-1805.

https://doi.org/10.1111/j.1559-1816.1993.tb01066.x

Kaduk, A., Genadek, K., Kelly, E. L., \& Moen, P. (2019). Involuntary vs. voluntary flexible work: Insights for scholars and stakeholders. Community, Work \& Family, 22, 412-442. https://doi.org/10.1080/13668803.2019.1616532

Kelliher, C., \& Anderson, D. (2010) Doing more with less? Flexible working practices and the intensification of work. Human Relations, 63, 83-106.

https://doi.org/10.1177/0018726709349199 
Ko, E. J., \& Kim, S. S. (2018). Intention to use flexible work arrangements: The case of workers in Korea and gender differences in motivation. Journal of Organizational Change Management, 31, 1438-1460. https://doi.org/10.1108/JOCM-01-2018-0001

Lambert, N., Stillman, T., Hicks, J., Kamble, S., Baumeister, R., \& Fincham, F. (2013). To belong is to matter: Sense of belonging enhances meaning in life. Personality and Social Psychology Bulletin, 39, 1418-1427. https://doi.org/10.1177/0146167213499186

Leslie, L. M., Manchester, C. F., Park, T. Y., \& Mehng, S. A. (2012). Flexible work practices: A source of career premiums or penalties? Academy of Management Journal, 55, 1407-1428. https://doi.org/10.5465/amj.2010.0651

Lilly, C. (2020) Working from home statistics. Finder. [Online] Available: https://www.finder.com/uk/working-from-home-statistics

Lundberg, U., \& Lindfors, P. (2002). Psychophysiological reactions to telework in female and male white-collar workers. Journal of Occupational Health Psychology, 7, 354-364. https://doi.org/10.1037/1076-8998.7.4.354

Masuda, A. D., Poelmans, S. A. Y., Allen, T. D., Spector, P. E., Lapierre, L. M., Cooper, C. L., ... Moreno-Velazquez, I. (2012). Flexible work arrangements availability and their relationship with work-to-family conflict, job satisfaction, and turnover intentions: A comparison of three country clusters. Applied Psychology: An International Review, 61, 1-29. https://doi.org/10.1111/j.1464-0597.2011.00453.x

Mirchandani, K. (2000). "The best of both worlds" and "cutting my own throat": Contradictory images of home-based work. Qualitative Sociology, 23, 159-182. https://doi.org/10.1023/A:1005448415689

Netemeyer, R., Boles, J., \& McMurrian, R. (1996). Development and validation of work-family conflict and family-work conflict scales. Journal of Applied Psychology, 81, 400-410. https://doi.org/10.1037/0021-9010.81.4.400

Nilles, J. M. (1998). Managing telework: Strategies for managing the virtual workforce. Wiley.

Ollier-Malaterre, A., Valcour, M., Den Dulk, L., \& Kossek, E. E. (2013). Theorizing national context to develop comparative work-life research: A review and research agenda. European Management Journal, 31, 433-447. https://doi.org/10.1016/j.emj.2013.05.002

Peretz, H., Fried, Y., \& Levi, A. (2018). Flexible work arrangements, national culture, organisational characteristics, and organisational outcomes: A study across 21 countries. Human Resource Management Journal, 28, 182-200.

https://doi.org/10.1111/1748-8583.12172

Powell, G. N., Francesco, A. M., \& Ling, Y. (2009). Toward culture-sensitive theories of the work-family interface. Journal of Organizational Behavior, 30, 597-616.

https://doi.org/10.1002/job.568 
Rasskazova, E., Ivanova, T., \& Sheldon, K. (2016). Comparing the effects of low-level and high-level worker need-satisfaction: A synthesis of the self-determination and Maslow need theories. Motivation and Emotion, 40, 541-555. https://doi.org/10.1007/s11031-016-9557-7

Richman, A., Civian, J., Shannon, L. L., Hill, E. J., \& Brennan, R. (2008) The relationship of perceived flexibility, supportive work-life policies, and use of formal flexible arrangements and occasional flexibility to employee engagement and expected retention. Community, Work \& Family, 11, 183-197. https://doi.org/10.1080/13668800802050350

Ryan, R. M., \& Deci, E. L. (2000). Self-determination theory and the facilitation of intrinsic motivation, social development, and well-being. American Psychologist, 55, 68-78.

https://doi.org/10.1037/0003-066X.55.1.68

Schüler, J., Sheldon, K., \& Fröhlich, S. (2010). Implicit need for achievement moderates the relationship between competence need satisfaction and subsequent motivation. Journal of Research in Personality, 44, 1-12. https://doi.org/10.1016/j.jrp.2009.09.002

Shockley, K., \& Allen, T. (2007). When flexibility helps: Another look at the availability of flexible work arrangements and work-family conflict. Journal of Vocational Behavior, 71, 479-493. https://doi.org/10.1016/j.jvb.2007.08.006

Spieler, I., Scheibe, S., Stamov-Roßnagel, C., \& Kappas, A. (2017). Help or hindrance? Day-level relationships between flextime use, work-nonwork boundaries, and affective well-being. Journal of Applied Psychology, 102, 67-87. https://doi.org/10.1037/apl0000153

Tietze, S., \& Musson, G. (2005). Recasting the home-work relationship: A case of mutual adjustment? Organization Studies, 26, 1331-1352.

https://doi.org/10.1177/0170840605054619

Van den Broeck, A., Ferris, L. D., Chang, C.-H., \& Rosen, C. C. (2016). A review of self-determination theory's basic psychological needs at work. Journal of Management, 42, 1195-1229. https://doi.org/10.1177/0149206316632058

Wayne, J. H., Matthews, R. A., Odle-Dusseau, H., \& Casper, W. J. (2019). Fit of role involvement with values: Theoretical, conceptual, and psychometric development of work and family authenticity. Journal of Vocational Behavior, 115.

https://doi.org/10.1016/j.jvb.2019.06.005

Weber, L. (2020, April 3). Navigating the coronavirus (a special report)-Full-time mom, full-time work: The life/work balance has always been precarious. Now it's overwhelming. Wall Street Journal, R.2.

Wei, T., \& Wong, L. (2020, March 14). Firms urged to stagger work hours, let staff work from home. The Straits Times. [Online] Available: https://www.straitstimes.com/singapore/fir ms-urged-to-stagger-work-hours-let-staff-work-from-home

Wilks, L., \& Billsberry, J. (2007). Should we do away with teleworking? An examination of whether teleworking can be defined in the new world of work. New Technology, Work and Employment, 22, 168-177. https://doi.org/10.1111/j.1468-005X.2007.00191.x 
World Health Organization. (2020a). Naming the coronavirus disease (COVID-19) and the virus that causes it. [Online] Available:

https://www.who.int/emergencies/diseases/novel-coronavirus-2019/technical-guidance/namin g-the-coronavirus-disease-(covid-2019)-and-the-virus-that-causes-it

World Health Organization. (2020b, March 11). WHO Director-General's opening remarks at the media briefing on COVID-19. [Online] Available:

https://www.who.int/dg/speeches/detail/who-director-general-s-opening-remarks-at-the-medi a-briefing-on-covid-19---11-march-2020

\section{Copyright Disclaimer}

Copyright for this article is retained by the author(s), with first publication rights granted to the journal.

This is an open-access article distributed under the terms and conditions of the Creative Commons Attribution license (http://creativecommons.org/licenses/by/4.0/). 